\title{
Female Peacekeepers and Gender Balancing: Token Gestures or Informed Policymaking?
}

\author{
Sabrina Karim \\ Emory University \\ skarim4@emory.edu \\ Kyle Beardsley \\ Emory University \\ kbeards@emory.edu
}

\begin{abstract}
Since the UN Security Council (UNSC) adopted Resolution 1325 (2000), which is referenced in most of the mandates for peacekeeping authorizations and renewals since, UN peacekeeping forces have begun a process of gender balancing. While we have seen an increase in the numbers of female peacekeepers during the decade 2000-2010 and variation in the distribution patterns of female military personnel, we do not know if female military peacekeepers are deploying to areas that are safest or to areas with the greatest need for gender-balanced international involvement. Since the decision-making authority in the allocation of peacekeeping forces rests with the troop contributing countries (TCCs), which might not have bought into the gender balancing and mainstreaming initiatives mandated by the UNSC, we propose and find evidence that female military personnel tend to deploy to areas where there is least risk. They tend not
\end{abstract}


to deploy where they may be most needed - where sexual violence and gender equity has been a major problem - and we find only a modest effect of having specific language in the mandates related to gender issues.

Keywords: peacekeeping, gender balance, UNSC 1325, "women, peace and security"

Authors' note: We are grateful for research support provided by the Folke Bernadotte Academy. We are indebted to Louise Olsson, Ismene Gizelis, members of the Folke Bernadotte Academy Working Group on Resolution 1325, members of the United Nations Mission in Liberia (UNMIL), David Sobek and the anonymous reviewers for helpful comments and discussion. 


\section{Introduction}

Within the literature on peacekeeping, there has been very little attention paid to the role of female military peacekeepers. In fact, while the literature explains variation of peacekeeping forces in general, it does not disaggregate by gender. With the passing of UNSC 1325, over the past decade, the numbers of women in peacekeeping have increased. In the 32 years between 1957 and 1989 a total of only twenty women served as UN peacekeepers, but today, of the approximately 125,000 peacekeepers, women constitute three percent of military personnel and ten percent of police personnel in UN peacekeeping missions. ${ }^{1}$ Figures 1 and 2 characterize the current state of the gender balance in UN peacekeeping forces. Figure 1 shows the average proportions of female peacekeeping personnel from 2006 to 2011, revealing that, while the overall proportions are still quite low, the trend is definitely upward. Figure 2 presents an even more positive portrayal of the situation by looking at the proportions of missions with some female peacekeepers. This shows that it is rather rare for missions to not have any female peacekeepers at all.

[Figures 1 and 2 about here]

Considering the UN's recent focus on gender balancing through UNSC 1325 and the increasing number of women in UN missions, understanding the distribution patterns of female military peacekeepers deserves attention. ${ }^{2}$ There is wide variation in UN missions when it comes to incorporating female military personnel. Women account for between zero and seven percent of mission deployments, with the missions in Nepal and

\footnotetext{
${ }^{1}$ See: "Women in Peacekeeping," < http://www.un.org/en/peacekeeping/issues/women/womeninpk.shtml> Retrieved October 20, 2012

${ }^{2}$ While we focus only on female military personnel, there is a need for future research to also look at the distribution patterns of female police and civilians.
} 
Cyprus leading the way over missions that have had a distinctly overt gender focus such as in Liberia. This provides us with an interesting puzzle: Why do some missions receive more women military personnel and others receive less?

We highlight three reasons why this variation in the gender balancing of peacekeeping is important. First, the variation provides insight into a nuanced understanding of the various ways in which the international community is attempting to address issues related to the gender imbalance of security forces, the vulnerability of women in conflict zones and the crucial role that women play in peacebuilding processes. Specifically, the study looks at women in the military as possible first responders to many problems women face including gender and sexual based violence. Second, it provides a baseline to begin understanding the efficacy of gender balancing in peacekeeping operations. If female peacekeepers tend to deploy to less violent and less protracted conflict environments, then this must be taken into account when studying the impact of gender balancing. Third, it provides a window into the principal-agent problems in the UN. For more than a decade the UNSC has provided much rhetoric with regard to gender balancing and mainstreaming but lacks the ability to enforce compliance; how to achieve such compliance is a crucial question with which institutionalist scholars constantly grapple.

In addressing this variation, this paper is the first to use statistical analyses on the UN data of peacekeeping military personnel since it has been disaggregated by gender. We analyze whether UN peacekeeping operations have, to date, been merely experiencing a growth in the gender balance in missions where the female personnel are kept out of harm's way, or if the women tend to be deployed to the post-conflict 
environments that might benefit the most from a better representation of female peacekeepers - those that have experienced high levels of gender-based violence, gender inequity or previous allegations of peacekeeper misconduct, as well as those where the UNSC mandates identified gender balancing, gender mainstreaming and the protection of women as priorities.

The focus of the study is on military female peacekeepers between 2006-2011. ${ }^{3}$ There are a number of reasons why we focus on military personnel. First, because the military embodies a highly masculine institution, where gender balancing is likely to be more difficult than in police and civilian components, we are able to discern what helps improve the gender balance in the most difficult cases. That is, it is especially meaningful to evaluate the 1325 regime by examining gender balance in such a sector that is prone to resist related policy changes. Second, in peacebuilding efforts, civilian UN employees are only responsible for developing policy, whereas UNPOL and the military contingents are responsible for helping to carry out these policies. For example, military contingents regularly engage in civil-military activities (CIMIC) and have more contact with the local population than civilian actors. The protection of women is primarily a security issue, and the military or UNPOL (with the host country's police) are often the first to address both small and large-scale violence. Moreover, the military personnel are in a position to know the needs of locals because they are involved in training the local police or military, engaging in projects with the local community and making policy recommendations to

\footnotetext{
${ }^{3}$ We analyze data from 2006-2011 because the UN only started disaggregating troop allocations by gender starting from 2006.
} 
mission headquarters. ${ }^{4}$ Third, highly visible concerns about the sexual misconduct of male peacekeepers-including sexual assaults and uses of prostitution-have led to increased interest in addressing the gender balance of peacekeeping missions in particular.

\section{Background: Gender and Peacekeeping}

The primary focus on the literature surrounding gender and conflict has been theoretical in nature. Many scholars have critically analyzed the way that the realm of international politics is dominated by masculine constructions, and have systematically demonstrated that women's experiences provide insight into matters of peace, war and violence (Enloe 1993; Enloe 1990, 2000, 2007; Pettman 1996; Sjoberg and Via, 2010, Tickner 1992, 2005; Wibben 2011).

Perhaps due to the attention brought by these scholars, over the last decades, the United Nations (UN) has made a concerted effort to incorporate women and women's agendas in conflict resolution by focusing on gender mainstreaming and balancing. With the passage of UNSC Resolutions 1325, 1820, 1888, 1889, and 1960, women's particular needs and their participation in post-conflict reconstruction activities have become a priority, at least in letter, in international efforts to increase security. Moreover, a number of peacekeeping mandates and guidelines, have been issued specifically for the encouragement of gender mainstreaming and balancing in the military component of

\footnotetext{
${ }^{4}$ The authors conducted over 100 interviews with female peacekeepers in the UNMIL mission to better understand mission dynamics and recruitment processes. Interviews with female military personnel in the UNMIL mission were conducted between May 10August 24, 2012. The interviews indicate that UNPOL and the military (especially in rural areas) have the most amount of contact with civilians and are also important in the formation of policy.
} 
missions (St. Pierre 2011). The purpose of guidelines such as those published by the DPKO/DFS in 2010 is to enhance the operational effectiveness of the military in UN operations. $^{5}$

Agencies such as UN Women and the UN Peacebuilding Commission have committed to two principles to achieve gender equality: gender balancing and gender mainstreaming (Mazurana et al 2005). Gender balancing refers to the degree to which women and men are represented within and participate in the full range of activities associated with political institutions such as the United Nations (including peacekeeping). This means that women are represented in equal numbers to that of men within missions. Gender mainstreaming refers to the process of assessing the implications for women and men of any planned action, including legislation, policies, or programs in all areas and at all levels so that the perceptions, experiences, knowledge, and interests of women are at the forefront when making policy decisions and implementing them (Mazurana, RavenRoberts, and Parpart 2005). While it is important to understand the effect of gender mainstreaming efforts and civilian initiatives such as the inclusion of gender focal points, the focus of this study is on gender balancing within military peacekeeping operations.

The concept of gender balancing initially was developed as a rights-based ideathat women, locally in post-conflict areas as well as internationally, should be able to participate in the same activities as men and have adequate representation (Carey 2001; Olsson 2001; Olsson and Truggestad 2001). It has gradually gained traction as part of a more functionalist argument. That is, the UN has increasingly started using a discourse

\footnotetext{
${ }^{5}$ See: DPKO/DFS Guidelines, "Integrating a Gender Perspective into the Work of the United Nations Military in Peacekeeping Operations," UN Department of Peacekeeping Operations and Department of Field Support, March 2010.
} 
of effectiveness to argue for the necessity of gender balancing, stating that the participation of women in military peacekeeping operations is essential for realizing mission goals.

While much of the recent efforts by IGOs and NGOs highlight the need for the incorporation of gender in the decision making processes at the global level, feminist scholars have argued that increasing the numbers of women does not necessarily translate into better outcomes (Jeffreys 2007; Jennings 2008; Simic 2010;). Indeed, gender balancing is much more complex than just attempts to meet certain quotas. Other literature on gender quotas, such as within legislatures and parties, suggests that they may not yield much in terms of the substantive representation of women (Baldez 2006; Bhavnani 2009; Caul 2001; Chen 2010; Dahlerup and Freidenvall 2005; Dahlerup 2008; Krook 2010; Tripp and Kang 2008). ${ }^{6}$ The assumption that adding women mitigates concerns about gender stereotypes in the security sector is untested, as the mere presence of women does not necessarily change military gender hierarchies and the militarized culture within the security institutions. For example, there have been many reports of rape within the U.S. military, indicating that despite the integration of women, there are still concerns around women's rights within the security establishment itself (Nelson 2002). Moreover, sometimes women are complicit in violence, such as in the case of Abu Ghraib. It is thus important to acknowledge that gender balancing per se may not equate to optimal outcomes related to gender rights, equality and security. While the improvements in the gender balance of UN missions is thus an achievement that sets the

\footnotetext{
${ }^{6}$ The recent proliferation of literature on gender quotas means that the idea that quotas matter in terms of substantively representing women is up not well established.
} 
stage for further reforms, it is worth turning a critical eye to whether the improvements could be more intentionally targeted to enhance their impact.

The movement toward gender balancing is part of a broader evolution of how peacekeeping is done. Since the end of the Cold War, traditional peacekeeping has gradually been replaced by broader, multi-dimensional peacekeeping operations. UN reforms starting with the Boutros-Ghali Agenda for Peace in 1992 laid the foundation for expanding the mandates of peacekeeping missions. Multi-dimensional peacekeeping missions are characterized by complex military, police, and civilian components, that not only play a role in enforcing peace agreements, but also in peacebuilding efforts that help reconstruct vital political and security institutions (Pouligny 2006). Moreover, a recent trend has been to authorize missions that focus solely on peacebuilding such as UNAMA in Afghanistan and BINUB in Burundi. The changes in mission scope and objectives are reflective of the international community's attempt to be more innovative and intentional in how it does peacekeeping. Some evidence shows that multidimensional peacekeeping has been successful in preventing conflict from recurring (Fortna 2008; Doyle and Sambanis 2006; Howard 2007).

An additional reform has been the increased balancing of military female personnel into peacekeeping missions. In 2009, in anticipation of the UNSC 1325's tenyear anniversary, UN Secretary General Ban Ki-moon launched a campaign to increase the share of female peacekeepers to ten percent in military units and twenty percent in police units by 2014. Moreover, peacekeeping mandates began to include gendered language in the 2000 's. With an increase in gender awareness in peacekeeping mandates, 
we need systematic explanations for the variation in the proportion of female military personnel actually deployed in different missions.

\section{Theoretical Framework: Peacekeeping Deployment and Troop-Contributing Country (TCC) Interests}

An obvious place to start to understand the distribution patterns of female military personnel is with the motivations of TCCs. While the international community and the UN send out calls for troop contributions, troop-contributing countries make all troop allocation decisions, and their priorities are not necessarily in line with those of the UNSC or UN Secretariat. TCCs weigh many factors in making allocation decisions, and there is variation among countries in what they prioritize. For example, poor countries benefit by sending troops because the UN trains the troops while compensating at a fixed rate that is meaningful to poorer countries. For this reason, developing states with large populations, such as Bangladesh, provide the largest share of peacekeepers, while richer countries pay for the missions instead of sending their militaries (Bove and Elia 2011).

Indeed, while we have seen an increase in the number of female peacekeepers globally, the numbers remain low. There are two possible reasons that the numbers remain so low despite the UN's call for increased female peacekeeping. First, these numbers reflect the underlying characteristics of the troop-contributing countries. That is, female peacekeeping allocation is likely determined by the simple availability of women in individual militaries. In this way, Kronsell (2012) suggests that the meager allocations of female peacekeepers reflect the composition of national militaries because that is the pool from which troop-contributing countries draw when deciding whom to send. And 
these numbers remain low within each TCC. Table 1 lists the ten countries that provided the most female military peacekeepers between November 2009 and December 2011. Many of the countries on this list have substantial representation of women in politics and strong records with regards to women's rights, which likely translates to a relatively strong representation of women in the domestic security forces. This is not universally the case, however, as the inclusion of Ethiopia in the top five, and the absence of any OECD states in the top five, show that gender issues at home in the TCCs cannot explain all the variation in the allocation of female peacekeepers. In another paper, we examine the subset of the TCCs for which we have data on the domestic gender balances of the armed forces and find that the correlation between the domestic gender balances and the gender balances of peacekeeping allocations is positive but not so strong that it swamps much of the variation (the correlation coefficient is less than 0.1) (Beardsley, Karim and Robbins, nd).

[Table 1 about here]

Second, in deciding to send female peacekeepers, TCCs consider the risks to sending women. There is general consensus that peacekeeping missions are likely to be authorized in the hardest cases (Fortna 2008; Gilligan and Stedman 2003; Greig and

\footnotetext{
${ }^{7}$ The first statistic is the percent of worldwide peacekeeping women for which each country is responsible. For example, South African peacekeeping women accounted for $13.5 \%$ of all peacekeeping women on average during this time period. The second statistic shows the percent of all peacekeepers, male or female, for which a country is responsible. When the first statistic is more than the second, it means that they are providing a higher percentage of female peacekeepers than their general peacekeeper contributions. The third statistic presents the ratio of female to total peacekeepers contributed by each country. For example, South Africa's total peacekeeping allocations consisted of $14.2 \%$ women on average during this time period. The statistics were calculated for each month during the observation period, and then average values were generated across all the periods in which each country had some level of peacekeeping deployment.
} 
Diehl 2005). Nevertheless, TCCs weigh the risks in determining whether and how to allocate their forces to these missions. Bove and Elia (2011) found that troop contribution is constrained by the tolerance of causalities and the sustainability of multiple and concurrent missions. The withdrawal of Belgian troops from Rwanda in 1994 as the genocide escalated reflects how risk undermines allocation.

There may be a greater political risk to governments when they send women to severe conflict zones because the way that war and gender are constructed contributes to the exclusion of women's equal participation in military activities. Goldstein (2003) argues that historically men have fought wars and women have not because of certain socialization processes, as well as some modest biological differences between the sexes. The interplay of gender roles affects the construction of women as peacemakers and men as warriors. Moreover, many militaries require certain capabilities and skills, such as driving, upper body strength, and shooting, which are stereotyped as being more associated with masculine characteristics. The stereotypes and criteria for joining the military reinforce the idea that the security sector is a male dominated space that might be unsuitable for women (Miller 1997). Gender balancing in peacekeeping contributions may be seen as disrupting a "masculine space" and thus unpopular at home, especially when the forces are likely to engage in combat.

Related, sending women to conflict zones might prove to be politically risky in the event that women are placed in harm's way. We have seen that troop-contributing countries have a major interest in keeping their military safe. This preference may be 
even stronger in the case of women. ${ }^{8}$ Because many countries' populations still hold conflicting views about women's participation in combat, negative opinions about sending women to combat-prone missions potentially abound. Related, women receive disproportionate attention in the media when they are injured such as in the case of Private Jessica Lynch (Sjolander and Trevenen 2010). TCCs may be reluctant to send female peacekeepers for fear of backlash if something were to happen to them.

Consistent with these biases, even though many countries have integrated women into their militaries, gender balancing in these institutions still reflects gendered stereotypes about women as weak and vulnerable. While women have been integrated into the security sector in some countries, they generally occupy jobs that are considered feminine, such as administrative positions, or medical related jobs (Enloe 2007). Few countries allow women in the military to perform combat duties (Keating, 2012). Even in the Israeli military, which is hailed as one of the most equal with respect to gender, women are often relegated to perform administrative tasks and suffer from gender stereotypes about being the weaker sex (Sasson-Levy and Amram-Katz 2007).

If gender stereotypes about women's abilities in the security sector are strong and states may be reluctant to send women based on the stereotypes and other risks, we should see that female peacekeepers deploy where there is the least amount of danger posed to the personnel. Places that are more dangerous - as measured in this study by the number of peacekeeper deaths historically for each mission and the severity of the conflict before the mission - are likely to face political limitations in the deployment of

\footnotetext{
${ }^{8}$ See Carpenter (2005) for an account of how norms for protecting women spread through intentional framing of various issues.
} 
female peacekeepers. They may also require women to have more combat and securityrelated training and physical attributes.

Table 2 presents some indication that women are more likely to be provided to those missions in which the peacekeeping personnel have less risk of facing combat. This table lists the ten missions with the highest ratio of female to total peacekeepers. The first statistic provides that average ratio during the time period of this study (August 2006 to December 2011), and the second one provides the average number of troops in each mission during this time period. ${ }^{9}$ As evident, many of the missions in this list are observer missions (UNTSO, MINURSO, UNOMIG, UNMOGIP) or political missions (UNMIN), where the likelihood of engagement with local hostile forces is minimal. Moreover, the second-best mission in terms of gender balance is in Cyprus, a relatively docile security environment. A more systematic analysis follows below, but a first look at this list suggests that the gender balance is likely to be strongest in environments with relatively small risk to the peacekeepers.

[Table 2 about here]

The analysis above that considers the primacy of TCCs generates the following hypothesis:

1. Female peacekeepers are more prevalent in missions that are the least risky.

\section{Theoretical Framework: The "Need" for Female Peacekeepers}

\footnotetext{
${ }^{9}$ Both statistics are averaged across the periods in which the missions actually had some deployment.
} 
There is a nascent but important literature on the joint relevance of peacekeeping and gender (Olsson and Truggestad 2001). ${ }^{10}$ Cohn (2004) argues that UNSC 1325 may contribute towards essentializing women as peacemakers and men as war-makers because the strategy used to sell the idea that women should have decision-making roles in peacemaking and peacebuilding largely centers on the belief that women are inherently peaceful. Women's NGOs and other advocates of UNSC 1325 have argued that women have functionalist qualities that contribute to peace, and thus should be able to participate in peace processes and post-conflict reconstruction. For example, host populations see women as more trustworthy and better at addressing women's issues, specifically in addressing gender-based violence and creating democratic institutions. Related arguments that hinge on women being essential for peacekeeping efficacy have been used to advocate for gender balancing in the military aspect of peacekeeping by the $\mathrm{UN}$ and other proponents (DPKO/DFS 2010).

According to functionalist arguments, female peacekeepers and other security personnel are essential to operational effectiveness because they can monitor unsanctioned behavior by other security personnel, enhance trust in and the reputation of security forces among the local population, and improve peacebuilding prospects in the host country (Bridges and Horsfall 2009; O'Neill and Vary 2011). This perspective contends that the inclusion of women in the security sector allows specialized attention to the specific needs of women and children in conflict, especially in addressing genderbased violence. Female peacekeepers are able to interact with an often-neglected fifty percent of the population about particular women's concerns such as sexual violence,

${ }^{10}$ See: International Peacekeeping special issue, Volume 17, Issue 2, April 2010. 
domestic abuse, and reproductive health. Female peacekeepers have a comparative operational advantage in sensitive situations like house searches, body searches, working in women's prisons, interviewing victims of SGBV, providing escorts for victims/witnesses, and screening women combatants at DDR sites.

Also related to this functionalist logic, some argue that female peacekeepers can prove vital to ensuring that local institution building incorporates a gendered view (gender mainstreaming). For instance, the UN argues that female peacekeepers were instrumental in increasing women's participation in voting in Timor-Leste, and Burundi). ${ }^{11}$ This increases operational legitimacy for the mission to a larger number of people (women). Some have also credited the all-female India police units in Liberia as having galvanized local women's aspirations to participate in the security sector. ${ }^{12}$

While some may argue that gender balancing may be more effective in the peacebuilding component of the mission more so than the military aspect of the mission, the DPKO/DFS Guidelines on gender outline similar ways in which having a female military presence enhances mission efficacy. They state that mixed patrolling teams are better than only male units and that "the presence of female military personnel can boost protection and response strategies as local women and children more readily confide in female peacekeepers-especially in the case of sexual violence" (DPKO/DFS 2010: 19).

\footnotetext{
${ }^{11}$ See also UN News Centre- "Greater action needed to include women in peacekeeping - UN study," http://www.un.org/apps/news/story.asp?NewsID=37486\&Cr=peacekeep\&Cr1, Retrieved October 21, 2012

12 See: “Addressing Conflict-related Sexual Violence: Analytical Inventory of Peacekeeping Practice." UNIFEM, < http://www.unwomen.org/wpcontent/uploads/2012/10/04D-An-Analytical-inventory-of-Peacekeeping-Practice.pdf $>$ Retrieved October 21, 2012
} 
The UN has highlighted some specific active ways in which female peacekeepers are beneficial to missions. ${ }^{13}$ Such ways include heightened abilities to empower women in the host community, screen female ex-combatants, assist female ex-combatants during the process of demobilization and reintegration into civilian life, widen the net of information gathering, perform the cordon and search of women, interview survivors of gender-based violence, mentor females in military academies, and interact with women in societies where women are prohibited from speaking to men. Moreover, the presence of women peacekeepers also can help to reduce conflict and confrontation, improve access and support for local women, empower women in the community, provide a greater sense of security to local populations including women and children, and broaden the skills available within a peacekeeping mission.

In essence, we should consider how female peacekeepers can have a positive impact in missions with greater gender need in two ways: through active representation and passive representation of women. Female peacekeepers are actively representing women when they promote the rights of women through their actions within the mission (Keiser et al. 2002; Meier; Nicholson-Crotty 2006). Active representation could be most important during outreach efforts such as providing medical care to civilians and visiting orphanages and female prisons by each military peacekeeping contingent. ${ }^{14}$ These efforts go above and beyond the scope of typical military contingents. The intentional promotion

\footnotetext{
${ }^{13}$ See "Women in Peacekeeping:" $<$ http://www.un.org/en/peacekeeping/issues/women/womeninpk.shtml $>$. Retrieved October 19, 2012

${ }^{14}$ The office of Civil Military Relations in each mission organizes the outreach activities for contingents. The examples provided are outreach activities conducted by different military contingents from the UNMIL mission.
} 
of voter turnout by women is another means that female peacekeepers actively represent women.

Female peacekeepers are passively representing women when their gender induces a change in behavior in the local population (Keiser et al. 2002; Meier and Nicholson-Crotty 2006). A related argument is that women provide legitimacy to the mission by virtue of being women (Bridges and Horsfall 2009; Kronsell 2012; Mazurana, 2003; Simic 2010). An example of this in peacekeeping might be if women become more likely to report sexual violence to another woman simply because she is a woman. Male peacekeepers might also become more reluctant to engage in sexual misconduct when women colleagues are present.

Related to passive representation, the UN claims that the pacifying presence of women in PKOs reduces aggressiveness and hyper-masculinity. ${ }^{15}$ The following statement from the UN Department for Peacekeeping Operations (DPKO) demonstrates this assumption: "Women's presence improves access and support for local women; it makes male peacekeepers more reflective and responsible; and it broadens the repertoire of skills and styles available within the mission, often with the effect of reducing conflict and confrontation" (cited in Rehm and Sirleaf 2002: 63). Similarly, Whitworth (2004) argues that peacekeeping operations, because they are not often associated with "traditional military combat," have a tendency to emasculate some men, who sometimes take out their aggression on the local population. The implication here is that women are better at keeping the peace, because they are less subject to "militarized masculinity."

\footnotetext{
${ }^{15}$ See: UN DPKO, 'Mainstreaming a Gender Perspective in Multidimensional Peace Operation', New York, July 2000, p.41. < http://www.peacewomen.org/assets/file/Resources/UN/dpko_mainstreaminggenderperspe ctive 2000.pdf $>$ Retrieved October 18, 2012
} 
Similarly, Kronsell (2012) analyzes if and how women bring legitimacy to peacekeeping missions by challenging the "militarized masculinity" within peacekeeping forces. Whereas sexual misconduct undermines the legitimacy of peacekeeping operations, female peacekeepers might help introduce a different culture and bolster accountability. For example, Kathryn Bolkovac, a U.S. female peacekeeper and whistleblower in Bosnia serves as an anecdotal case of a woman holding male peacekeepers accountable for their actions (Bolkovac and Lynn 2011).

If a functionalist logic related to the active and passive benefits of female peacekeepers strongly shapes the decision process in allocating female peacekeepers, then female military peacekeepers should deploy to where there is greater gender-based needs in the host country (both institutional need and need based on sexual exploitation). If women have particular characteristics that make them better to address particular gender needs within the scope of the work that the military engages in including patrolling, civilian outreach initiatives, conducting searches, disarmament, demobilization and reintegration efforts, and providing protection for women against sexual violence, and if peacekeeping resources are allocated based on maximizing efficacy, we should expect that female military peacekeepers should go to where there is the greatest amount of gendered need. That is, female military personnel should go where domestic institutions for women are weak, where there is higher gender inequality, and where there are higher levels of sexual exploitation. We should also see that female military peacekeepers go to places where gender issues are mentioned in the UNSC resolutions that define the mandates, as the UNSC signals the priority of directly addressing such issues. This leads to the following hypotheses: 
2. Female military peacekeepers are more prevalent where there is greater genderbased needs in the host country.

3. Female military peacekeepers are more prevalent where there are specific UN mandates for the security of women.

\section{Research Design}

Our goal is to test whether distribution patterns of female peacekeeper deployments are correlated more strongly with limited risk to the deployed peacekeepers or with where there is the greatest amount of need on behalf of the women in the host country. The unit of analysis is the country-year in which each peacekeeping operation resides. We begin with the set of PKOs, and not a broader set of countries, because it is reasonable to assume that the decision by the Security Council to authorize a peacekeeping mission is not much affected by a priori considerations about the gender composition of potential peacekeeping forces. In this way, it is not likely that the analysis is plagued by selection bias problems because the assignment of peacekeeping missions is not selecting on the dependent variable.

\section{Dependent Variable}

The dependent variable is a measure of the proportion of female peacekeepers in each country's mission out of the total peacekeepers in the mission. We collected data from the UN Gender Statistics Database from the UN Department of Peacekeeping website and focus our attention on the distributions of military observers, staff officers, and contingent troops between August 2006 and December 2011. We primarily use data on 
military peacekeepers because the data on police peacekeepers are not reported until February 2009. ${ }^{16}$ Starting from August 2006, the UN has reported data on the monthly gender compositions of peacekeeping operations. We aggregate from the month to the year by using the average proportion of each month in the respective years. ${ }^{17}$ Missions such as UNMIS and MONUC that were simply renamed (to UNMISS and MINUSCO, respectively) are treated as continuous missions. The proportions are converted to percentages by multiplying times 100 .

\section{Independent Variables}

To test the first hypothesis regarding the safest environments, we include the rate of peacekeeper deaths in each mission, reported by the UN Department of Peacekeeping Operations. We also use fatality estimates during previous conflict episodes in the host country, from the UCDP battle-related deaths data. To code this indicator of recent violence severity, we look at the highest yearly amount of battle-related fatalities in the previous ten years. Higher numbers of fatality and peacekeeper deaths correspond to more risky missions. As a final measure, we include the GDP per capita of the host country (lagged one year), from the World Bank, with the premise that more developed countries are less likely to experience a relapse in violence and pose less of a threat to the security of the peacekeepers.

\footnotetext{
${ }^{16} \mathrm{It}$ is worth noting that the list of missions with the strongest gender balance with regard to police forces does not have much overlap with those in Table 2 above. We leave systematic analysis of the allocation of peacekeeping police forces to future research with more data.

${ }^{17}$ We aggregate to the year because all of our independent variables only vary at annual intervals, and there is only slight variation from month to month in the gender balance of peacekeeping forces.
} 
To test the second hypothesis, we use indicators that capture the extent to which women are vulnerable to intrastate violence. The first is the estimated number of civilians killed in recent armed conflict episodes, from Eck and Hultman's data on one-sided violence that is part of the Uppsala Conflict Data Program (Eck and Hultman 2007). Specifically, we include the number of yearly one-sided fatalities in the most violent year during the previous ten years. While this measure does not count the number of females specifically that were killed, we assume that females are much more likely to be affected by violence in states in which this variable is high than in states in which it is low. We also look at the number of peacekeeping allegations, which picks up on the potential need for female peacekeepers in places where peacekeepers have previously committed acts of sexual violence. The UN tracks the number of allegations of sexual abuse per mission each year starting from $2007 .^{18}$ As a measure of gender inequality, we include the percentage of women in parliament in the host country, which indicates the extent to which females have a political voice that they can leverage to address their needs locally. Related, we use the World Bank's numbers for the gross ratio of primary school enrollment for girls, where lower scores indicate higher inequality and thus greater need. We also look at security levels for women using Mary Caprioli's WomanStats database to look at the ratings on the level of physical security for women, discrepancy between law and practice concerning women, scores for rape/sexual assault, and female infanticide (Caprioli et al. 2009). Higher levels of these four indices correspond to higher need as they convey a dearth of human-rights protections available to females in conflict-prone

${ }^{18}$ See: UN Conduct and Discipline Unit: $<$ http://cdu.unlb.org/Statistics/AllegationsbyCategoryofPersonnelSexualExploitationand Abuse/AllegationsforAllCategoriesofPersonnelPerYearSexualExploitationandAbuse.aspx $>$ Retrieved January 18, 2012 
areas. The logic here is that females will be more vulnerable to become victims of violence in conflict-prone areas when local legal institutions are unable to protect them. ${ }^{19}$

In order to test the third hypothesis, UN mandates to each mission were coded based on whether the UNSC resolutions that defined the mandates included any language on gender issues, gender mainstreaming, Resolution 1325, sexual violence, and the need for protecting women. Separate dummy variables for each mandate characteristic are included in the models, since they are not mutually exclusive. The point of including these variables is to see if female peacekeepers are more likely to deploy to conflicts when the UNSC has identified gender needs in the mandates.

\section{Control Variables:}

For all models, we include the measure of logged GDP per capita because the underlying level of development is likely to correlate with the other measures of gender inequality and security and is also expected to shape the gender balance of peacekeeping missions via the risk mechanism of the first hypothesis. So, we can interpret the effects of the other variables described above as the effects after having taken into account development. We additionally control for whether each mission is a traditional, political or multidimensional mission, since each type of mission has qualitatively different mandates from the others. Traditional missions only involve observation by military personnel; civilian missions only involve assistance to local institutional building and security sector reform; and multidimensional missions are authorized under Chapter VII of the UN Charter and involve both military and political components. For use in the models, we

\footnotetext{
${ }^{19}$ We also considered using the UN's Gender Inequality Index (GII) to test this hypothesis, but there was too much missing data.
} 
include the dummies for traditional and political missions, with multidimensional missions left as the reference category. ${ }^{20}$

\section{Estimation}

We test the hypotheses using an OLS random effects model. With mission-year data, there is likely to be unit heterogeneity that could induce serial correlation, and we adjust for this using random effects. ${ }^{21}$ We also report standard errors that are robust to clustering on each mission in order to address additional correlation in the errors among observations of the same mission. We also ran Tobit models for robustness, with the observations in which there were no female peacekeepers treated as censored. The findings from the Tobit models are very similar to those in the OLS models, and we do not rely on these models - or Heckman selection models either - because there were only two missions (BINUB in Burundi and UNIOSL in Sierra Leone) that never had any female peacekeepers in the entire time period.

For each of the hypotheses, we employ multiple measures of the same underlying concepts. Especially for the second and third hypotheses, the measures are highly correlated with each other. We thus test each measure of gender need and mandate language separately, since we do not want to "control" for similar measures of the same concept with such a limited sample size. We also use factor analysis to allow each of the

\footnotetext{
${ }^{20}$ In other models to test for robustness, we also tried controlling for recent battle-related fatalities and the duration of each peacekeeping mission to account for additional heterogeneity in the missions in each model. Neither of these variables proved statistically significant and did not affect the other findings in any of the models and so we omit them from the models here.

${ }^{21} \mathrm{We}$ do not use fixed effects because the interesting variation is between units and not within units.
} 
measures of the same concepts to load onto a single variable. We then include the three factors that represent the three underlying concepts of risk, gender need and mandate language in a common model to assess the relationship between these concepts and the gender balance of the peacekeeping missions while holding constant variation in the other concepts.

\section{Results}

We find evidence that TCCs send female military personnel to the safest missions, providing support for the first hypothesis. Table 3 presents Model 1, which contains three variables useful to assess the relative safety of the peacekeepers. The substantive effects of these variables can be seen in Figure 3, which provides the expected changes in the percentage of women in a mission as each independent variable increases by two standard deviations. The most direct indicator is the number of peacekeeper deaths in each mission, which is negatively associated with the percentage of female peacekeepers in each mission, and the effect is statistically significant, as expected. Substantively, an increase in the number of peacekeeper deaths by two standard deviations - which amounts to about 18 - leads to an expected decrease in the percentage of female peacekeepers by 1.18 percentage points, which is substantial given that the average percentage in the sample is only $2.66 \%$.

[Table 3 about here]

In terms of the other two indicators of risk - the severity of recent violence and GDP per capita - the story is similar. While the coefficient on the battle deaths variable is not statistically significant, it is negative. The GDP per capita variable is statistically 
significant and positive, which confirms that female peacekeepers are more likely to be deployed in countries that are more developed. This is consistent with the notion that TCCs are more likely to send them to the post-conflict environments that are relatively safe. Substantively, an increase by two standard deviations in GDP per capita - a little over $\$ 24,000$ - increases the expected percentage of female peacekeepers by 1.9 percentage points. This effect, although robustly statistically significant, is actually a bit small substantively: $\$ 24,000$ per capita is a huge amount for most post-conflict states.

We do not find much support for the latter two hypotheses. To examine the second hypothesis, Table 4 presents the models that include indicators of local need for female peacekeepers. Figure 4 presents the substantive effects. None of the variables, except for GDP per capita discussed above, are statistically significant in these models. The ratio of girls in primary school is approaching statistical significance, but the coefficient is positive, suggesting that women are more likely sent to missions in countries that are already doing relatively well with regard to gender equality in the schools. We thus do not see evidence confirming that the female peacekeepers are being sent to the conflicts with the highest rates of gender-based violence, gender inequality and gender insecurity. Given the relatively small sample size of our data and the modest ability for the models to explain the variance in the dependent variable, we cannot confidently conclude that there is no relationship between each of these measures of need and the gender balance of the peacekeeping missions. That being said, the fact that we did not find a strong effect for any of these eight measures does support an interpretation that such needs do not play much of a role in the decision processes that lead to the allocation of female peacekeepers by troop contributing countries. 


\section{[Table 4 about here]}

With regard to the third hypothesis, there is only modest evidence that the language in the UNSC resolutions which set the PKO mandates actually influences the gender balance of the peacekeeping operations. These results are seen in Table 5, and the substantive effects are seen in Figure 5. In Model 10, we see that mentions of gender in the mandates do positively correlate with the percentage of female peacekeepers - the inclusion of such language corresponds to a 1.4 percentage-point increase in female peacekeepers. The inclusion of other language related to gender mainstreaming, Resolution 1325, sexual violence or the protection of women do not significantly correlate with the gender balance of the peacekeeping missions.

\section{[Table 5 about here]}

Thus far, each of the hypotheses have been tested using multiple measures and separately from each other. As a final step, we use factor analysis to generate single variables on which are loaded the variation of the multiple measures of each underlying concept. We include these variables into a single model, shown in Table 6. Again, we see that the indicator of risk is statistically significant, while the indicators of gender needs and mandate language are not. ${ }^{22}$ In looking at the factor loadings, the mission risk factor is negatively correlated with GDP per capita and positively correlated with peacekeeper fatalities and battle deaths. ${ }^{23}$ This means that higher values of this factor correspond to

\footnotetext{
${ }^{22}$ Note that GDP per capita is not statistically significant here, as it is one of the components of the mission-risk factor.

${ }^{23}$ The loading for the gender needs factor indicates that it is positively related to the underlying measures of gender inequality and insecurity. The loading for the mandate language factor indicates that it is positively related to the mentioning of gender issues.
} 
more risk, and the negative coefficient thus indicates that higher proportions of women are sent to missions that are relatively safer.

\section{Discussion and Conclusions}

This article finds support for the notion that the relative risk of a mission influences the allocation patterns of female military personnel. The gender balance for the military in UN missions is stronger in the missions that are less dangerous to the personnel. This could mean that TCC countries are influenced by gender stereotypes of women in the military, which is a continuation of the reluctance of most countries to allow women to serve in combat roles. ${ }^{24}$ The perception is that men are better equipped to handle the security environments in the more dangerous missions both because the military institution is seen as a masculine space, and also because women may be seen, rightly or not, as lacking the proper abilities to engage effectively in combat. Moreover, TCCs may not want to deal with the public costs - also influenced by stereotypes of males being more fit for dying honorably on the battlefield-of their women dying in such missions, so they avoid sending women to them. These incentives help explain why we see a greater abundance of female military personnel in missions such as UNTSO (monitoring the stable interstate relations between Israel and its neighbors), UNMIN (Nepal) and UNFICYP (Cyprus), and less allocations to, say, the Sudanese conflicts or Haiti. The most recent UN observer mission to Syria, where no female military personnel were deployed despite the plight of women and children in the conflict, also exhibits these incentives.

\footnotetext{
${ }^{24}$ We are, however, seeing an increase in the willingness for Western countries to deploy women to dangerous places such as Iraq and Afghanistan, where the death toll for soldiers is very high.
} 
While our findings should not be taken to suggest that the gains in gender balancing of peacekeeping missions over the past decade have been in vain, the missed opportunity to have more meaningful gender balancing should not be diminished. The military and police have certain skills that are important in providing security to women, especially when it comes to issues of gender based violence. Female military personnel have already proven to be important resources that serve on the ground, implementing initiatives such as women's literacy programs, sexual harassment policies, and training programs on gender for male peacekeepers. Moreover, there is recent evidence suggesting that contact with women in the security sector encourages locals to join the security sector. $^{25}$ This means that there is a role for female personnel in both peacekeeping and peacebuilding.

If TCCs are allocating female military personnel based on relative risk for a mission, it means that female military peacekeepers are not allocated such that they can change the efficacy of peacekeeping in the way that the UN has advocated. They will not be able to improve the security of women, be beacons for gender equality, or improve local trust in security institutions if they are not deployed to the post-conflict environments in which there are high rates of gender-based violence, gender inequality and gender insecurity. Instead, at this point, it appears that these are merely token females taking part in the military aspect of peacekeeping.

We may find a different conclusion for the women participating in the police side of the UN missions. More women are deployed through UNPOL and as police officers rather than as military personnel. They also participate more in political peacebuilding

\footnotetext{
${ }^{25}$ See Karim (nd), describing a field survey in Monrovia, Liberia.
} 
efforts than the military contingency. Civilian recruitment is very different from military or UNPOL recruitment. Civilians choose their mission and they are employed by the UN, so country of origin interests are not a factor, and thus do not fit the theoretical framework in this study. We suggest that more research should be conducted to look at the distribution patterns and allocation decisions of female police and civilian personnel to see if the findings are similar to that of female military peacekeepers presented here.

The positive finding for the mention of gender in the mandate also cannot go ignored. This finding provides a modest affirmation that women may go to where they are most needed. However, beginning around 2005, almost all new mandates included language pertaining to gender issues, especially with regards to sexual exploitation committed by peacekeepers. While the increase in the use of language that prioritizes the issues related to gender, peace and security is a notable development in itself, and could be important in explaining the overall increase in the proportion of women in peacekeeping missions, it is not clear if having more language than what is used currently will do much to help entice TCCs to provide even more women.

There are two additional implications from this research. First, on a more theoretical plane, this study clarifies the extent to which the UN struggles with the principal-agent problem. Despite influence that the members of the Security Councilespecially the P-5-have in the UN, they are frequently unable to induce compliance with their edicts. Especially when the UNSC is pushing initiatives that more closely resemble public goods, it is quite difficult to get other member states on board and to follow through with the requisite commitments. The UN of course is certainly not an "it" but a 
"they" and this is evident in the struggles to improve the gender balance of peacekeeping forces in ways that could make a difference.

Second, from a policy perspective, the UN—especially the UNSC and the office of the Secretary-General-should find better ways to improve the gender balance in the military aspect of peacekeeping forces in ways that better make a difference to the security environment. Perhaps there could be additional monetary incentives for troopcontributing countries to actually include women on missions that could use their assistance. Other suggestions from interviews with female military personnel from the UNMIL mission include providing better training for women in national militaries in computer, driving, and combat skills, all areas where women have less capacity than men in some TCC country militaries. ${ }^{26}$ Moreover, gender programs at the Kofi Annan Institute and a bilateral partnership between Ghana and Norway in which Norway gives technical assistance to Ghanaian women in the security sector provide examples of policies that may help enhance the gender balance in UN Missions. Lastly, a network of female military personnel who have participated in missions could be established so that women feel that they are able to participate in missions. These suggestions may help TCC countries send more women to where they may be most needed to address issues related to gender, peace and security.

\footnotetext{
${ }^{26}$ Interviews with female military personnel in the UNMIL mission were conducted between May 10-August 24, 2012.
} 


\section{REFERENCES}

Baldez, Lisa. 2006. "The Pros and Cons of Gender Quota Laws: What Happens When You Kick Men Out and Let Women In?” Politics \& Gender 2(01): 102-109.

Beardsley, Kyle, Sabrina Karim and Arianna Robbins. nd. "Voluntary Compliance with Global Initiatives: Gender Balance in Security Personnel." Working paper.

Bhavnani, Rikhil R. 2009. "Do Electoral Quotas Work after They Are Withdrawn? Evidence from a Natural Experiment in India." American Political Science Review 103(01): 23-35.

Bolkovac, Kathryn and Cari Lynn. 2011. The Whistleblower: Sex Trafficking, Military Contractors, and a Woman's Fight for Justice. New York: Palgrave.

Bove, Vincenzo, and Leandro Elia. 2011. "Supplying peace: Participation in and troop contribution to peacekeeping missions." Journal of Peace Research 48(6): 699 714.

Bridges, D., and D. Horsfall. 2009. "Increasing Operational Effectiveness in UN Peacekeeping." Armed Forces \& Society 36(1): 120.

Caprioli, Mary, Valerie M. Hudson, Rose McDermott, Bonnie Ballif-Spanvill, Chad F. Emmett, and S. Matthew Stearmer. 2009. "The WomanStats Project Database: Advancing an Empirical Research Agenda." Journal of Peace Research 46 (6): 113.

Carey, Henry F. 2001. "'Women and Peace and Security': The Politics of Implementing Gender Sensitivity Norms in Peacekeeping." International Peacekeeping 8 (2): 49-68.

Carpenter, R. Charli. 2005. "'Women, Children and Other Vulnerable Groups': Strategic Frames and the Protection of Civilians as a Transnational Issue." International Studies Quarterly 49: 295-334.

Caul, Miki. 2001. "Political Parties and the Adoption of Candidate Gender Quotas: A Cross-National Analysis.” Journal of Politics 63(4): 1214-1229.

Chen, Li-Ju. 2010. “Do Gender Quotas Influence Women's Representation and Policies?” The European Journal of Comparative Economics 7(1): 13-60.

Cohn, Carol. 2004. "Mainstreaming Gender in UN Security Policy: A Path to Political Transformation?" Boston Consortium on Gender, Security and Human Rights, Working Paper No. 204 
Dahlerup, Drude, and Lenita Freidenvall . 2005. "Quotas as a 'fast track' to equal representation for women." International Feminist Journal of Politics 7(1): 2648.

Dahlerup, Drude. 2008. "Gender Quotas - Controversial But Trendy." International Feminist Journal of Politics 10(3): 322-328.

DPKO/DFS Guidelines. 2010. "Integrating a Gender Perspective into the Work of the United Nations Military in Peacekeeping Operations," UN Department of Peacekeeping Operations and Department of Field Support, March

Doyle, Michael W. and Nicholas Sambanis. 2006. Making War and Building Peace: United Nations Peace Operations. Princeton: Princeton University Press.

Eck, K., \& Hultman, L. (2007). One-Sided Violence Against Civilians in War Insights from New Fatality Data. Journal of Peace Research, 44(2), 233-246.

Enloe, Cynthia. 1990. Bananas, Beaches and Bases: Making Feminist Sense of International Politics. Los Angeles: University of California Press.

- 2007. Globalization and Militarism: Feminists Make the Link. Plymouth: Rowman \& Littlefield Publishers.

- 2000. Maneuvers: The International Politics of Militarizing Women's Lives. 1st ed. Los Angeles: University of California Press.

Enloe, Cynthia H. 1993. The Morning After: Sexual Politics at the End of the Cold War. Los Angeles: University of California Press.

Fortna, Virginia Page. 2008. Does Peacekeeping Work?: Shaping Belligerents' Choices after Civil War. Princeton: Princeton University Press.

Gilligan, Michael, and Stephen John Stedman. 2003. "Where Do the Peacekeepers Go?1.” International Studies Review 5(4): 37-54.

Goldstein, Joshua S. 2003. War and Gender: How Gender Shapes the War System and Vice Versa. Cambridge: Cambridge University Press.

Greig, J. Michael, and Paul F. Diehl. 2005. "The Peacekeeping-Peacemaking Dilemma." International Studies Quarterly 49(4): 621-645.

Howard, Lise Morjé. 2007. UN Peacekeeping in Civil Wars. 1st ed. Cambridge: Cambridge University Press.

Jeffreys, Sheila. 2007. "Double jeopardy: Women, the US military and the war in Iraq." Women's Studies International Forum 30(1): 16-25.

Jennings, K. M. 2008. "Protecting Whom? Approaches to Sexual Exploitation and Abuse in UN Peacekeeping, Operations, Fafo, Oslo 
Karim, Sabrina. nd. "Gender Balancing in Security Sector Reform: A Path to Restoring Institutional Legitimacy in Post-Conflict Liberia?" Working paper.

Keating, Joshua. 2012. "Where a Woman's Place is on the Front Lines," Foreign Policy, $<$ http://www.foreignpolicy.com/articles/2012/02/10/where_a_womans_place_is on_the_front_lines?page $=0 \% 2 \mathrm{C} 0 \#$.TzZ64M4FmSw.email $>$ retrieved March 8 , 2012

Keiser, Lael R. et al. 2002. "Lipstick and Logarithms: Gender, Institutional Context, and Representative Bureaucracy." American Political Science Review 96(03): 553564.

Kronsell, Annica. 2012. Gender, Sex and the Postnational Defense: Militarism and Peacekeeping. New York: Oxford University Press, USA.

Krook, Mona Lena. 2010. Quotas for Women in Politics: Gender and Candidate Selection Reform Worldwide. New York: Oxford University Press, USA.

Mazurana, Dyan. 2003. "Do Women Matter in Peacekeeping? Women in Police, Military and Civilian Peacekeeping." Canadian Woman Studies 22(2). http://pi.library.yorku.ca/ojs/index.php/cws/article/view/6488.

Mazurana, Dyan, Angela Raven-Roberts, and Jane Parpart, eds. 2005. Gender, Conflict, and Peacekeeping. 1st US Paperback. Oxford: Rowman \& Littlefield Publishers.

Meier, Kenneth J, and Jill Nicholson-Crotty. 2006. "Gender, Representative Bureaucracy, and Law Enforcement: The Case of Sexual Assault." Public Administration Review 66(6): 850-860.

Miller, Laura L. 1997. "Not Just Weapons of the Weak: Gender Harassment as a Form of Protest for Army Men.” Social Psychology Quarterly 60(1): 32-51.

Nelson, Terri Spahr. 2002. For Love of Country: Confronting Rape and Sexual Harassment in the U.S. Military. 1st ed. New York: Routledge.

Olsson, Louise. 2001. "Gender Mainstreaming in Practice: The United Nations Transitional Assistance Group in Namibia." International Peacekeeping 8 (2): 97 110.

Olsson, Louise, and Torrun L. Truggestad, eds. 2001. Women and International Peacekeeping. 1st ed. Portland: Frank Cass Publishers.

O'Neill, Jacqueline and Jarad Vary. 2011. "Allies and Assets: Strengthening DDR and SSR through Women's Inclusion." In Melanne A. Civic and Michael Miklaucic, eds. Monopoly of Force: The Nexus of DDR and SSR. Washington: National Defense University Press, pp. 77-108. 
Pettman, Jan Jindy. 1996. Worlding Women: A Feminist International Politics. New York: Routledge.

Pouligny, B. (2006). Peace operations seen from below: UN missions and local people. Bloomfield, CT: Kumarian Press.

Rehn, Elisabeth and Ellen Johnson Sirleaf. 2002. Women, War, Peace: The Independent Experts' Assessment on the Impact of Armed Conflict on Women and Women's Role in Peace-building, New York: UNIFEM.

Sasson-Levy, Orna, and Sarit Amram-Katz. 2007. "Gender Integration in Israeli Officer Training: Degendering and Regendering the Military.” Signs 33(1): 105-133.

Simic, Olivera. 2010. "Does the Presence of Women Really Matter? Towards Combating Male Sexual Violence in Peacekeeping Operations." International Peacekeeping (13533312) 17(2): 188-199.

Sjoberg, Laura, and Sandra E Via. 2010. Gender, War, and Militarism: Feminist Perspectives. 1st ed. Santa Barbara: Praeger.

Sjolander, Claire Turenne, and Kathryn Trevenen. 2010. "One of the Boys?" International Feminist Journal of Politics 12(2): 158-176.

St. Pierre, Kristine. 2011. "Implementing the Women, Peace, and Security Agenda, in Peace Operations: Overview of Recent Efforts and Lessons Learned," Pearson Centre Background Paper.

Tickner, J. Ann. 2005. "What Is Your Research Program? Some Feminist Answers to International Relations Methodological Questions." International Studies Quarterly 49(1): 1-22.

Tickner, J. Ann. 1992. Gender in International Relations. 0 ed. Columbia University Press.

Tripp, Aili Mari, and Alice Kang. 2008. "The Global Impact of Quotas On the Fast Track to Increased Female Legislative Representation." Comparative Political Studies 41(3): 338-361.

Whitworth, S. (2004). Men, militarism, and UN peacekeeping: a gendered analysis. Boulder, Lynne Rienner Publishers.

Wibben, Annick T. R. 2011. Feminist Security Studies: A Narrative Approach. 1 st ed. New York: Routledge. 


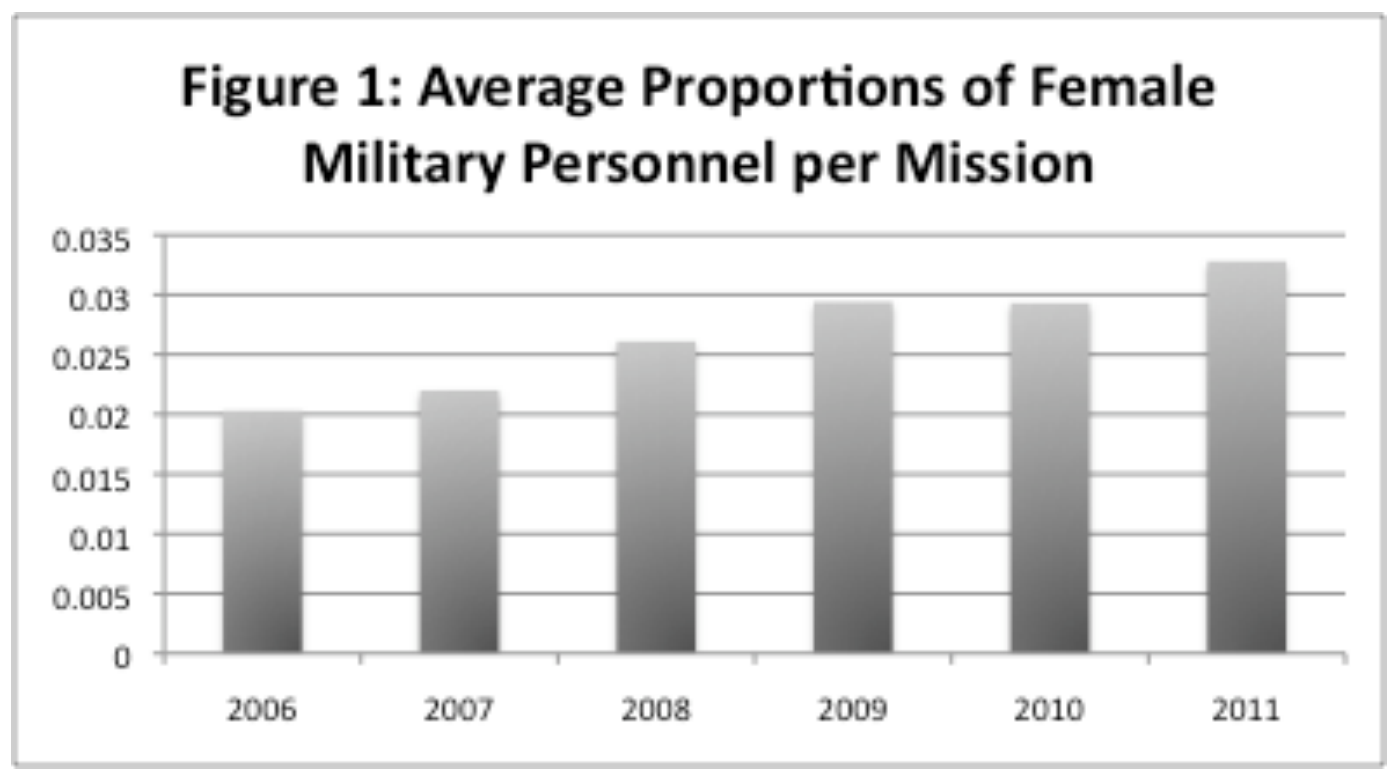




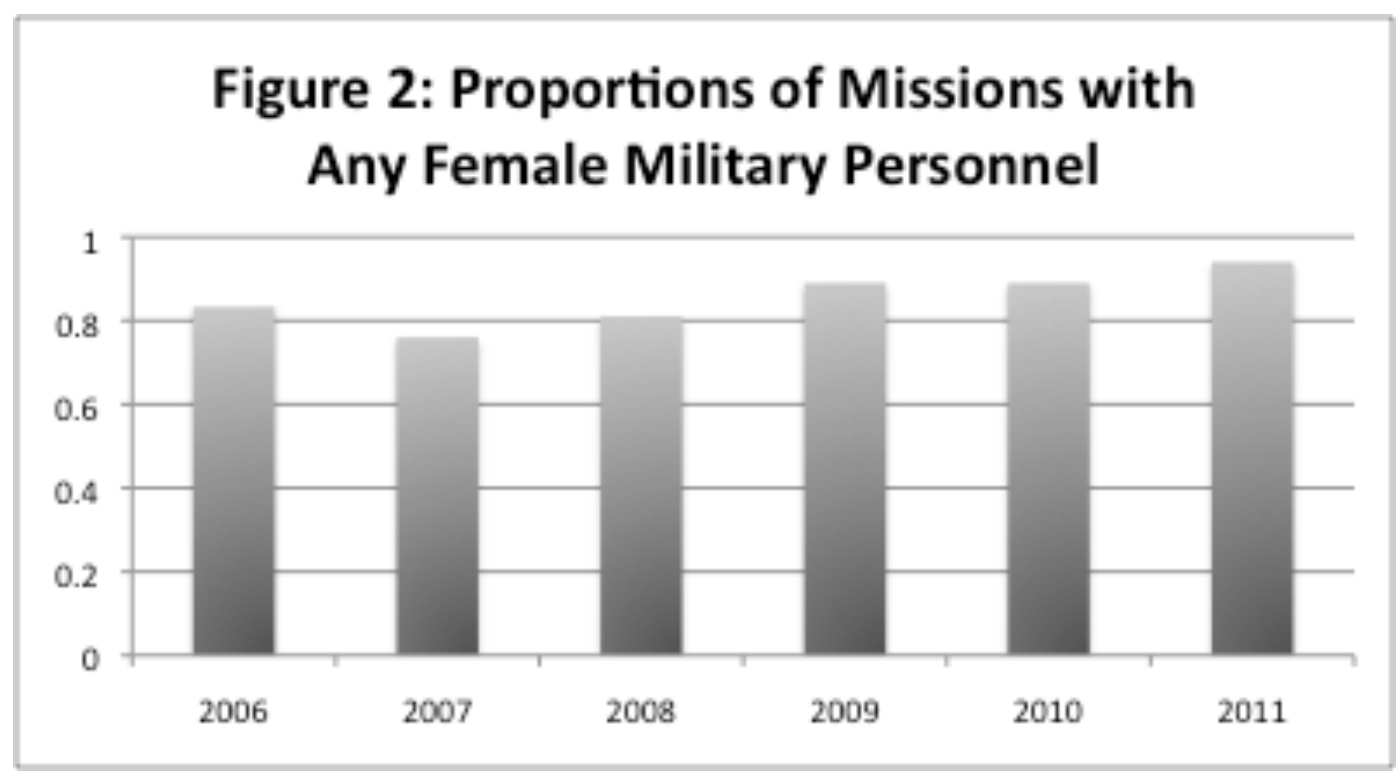




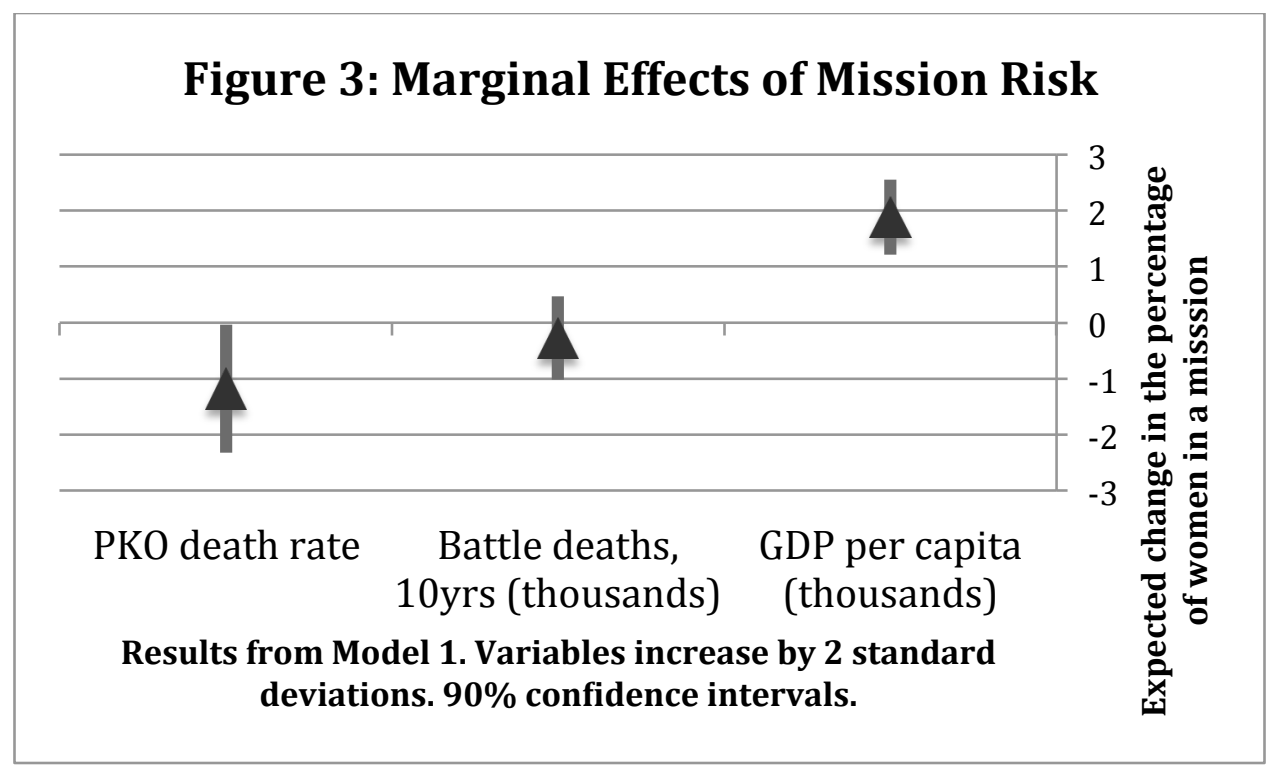


Figure 4: Marginal Effects of Gender Needs

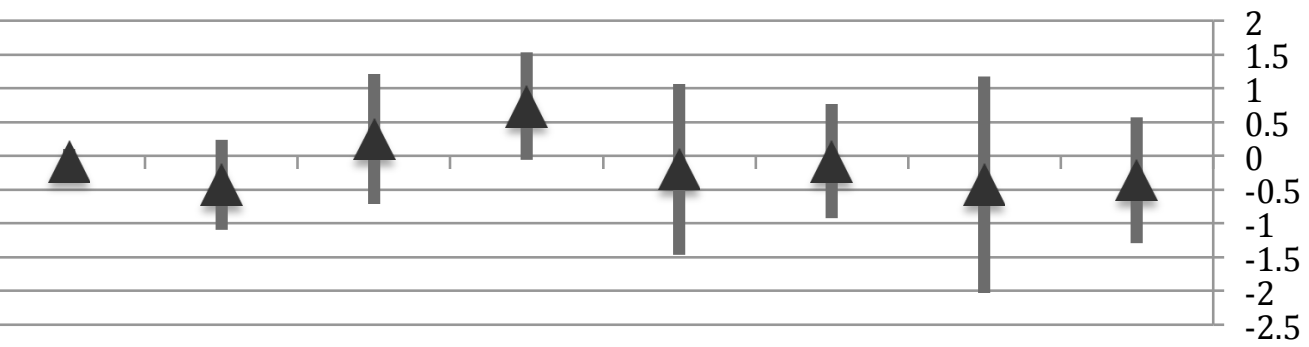

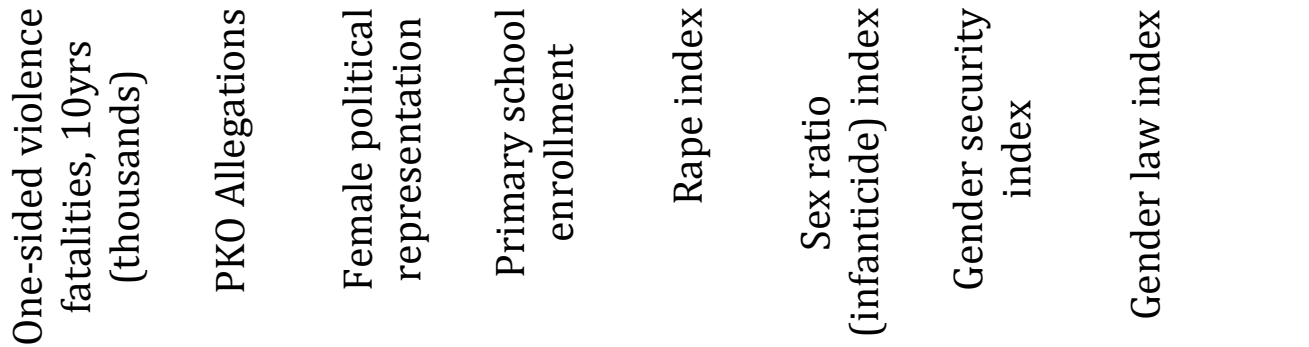

Results from Models 2-9. Variables increase by 2 standard deviations. $90 \%$ confidence intervals. 


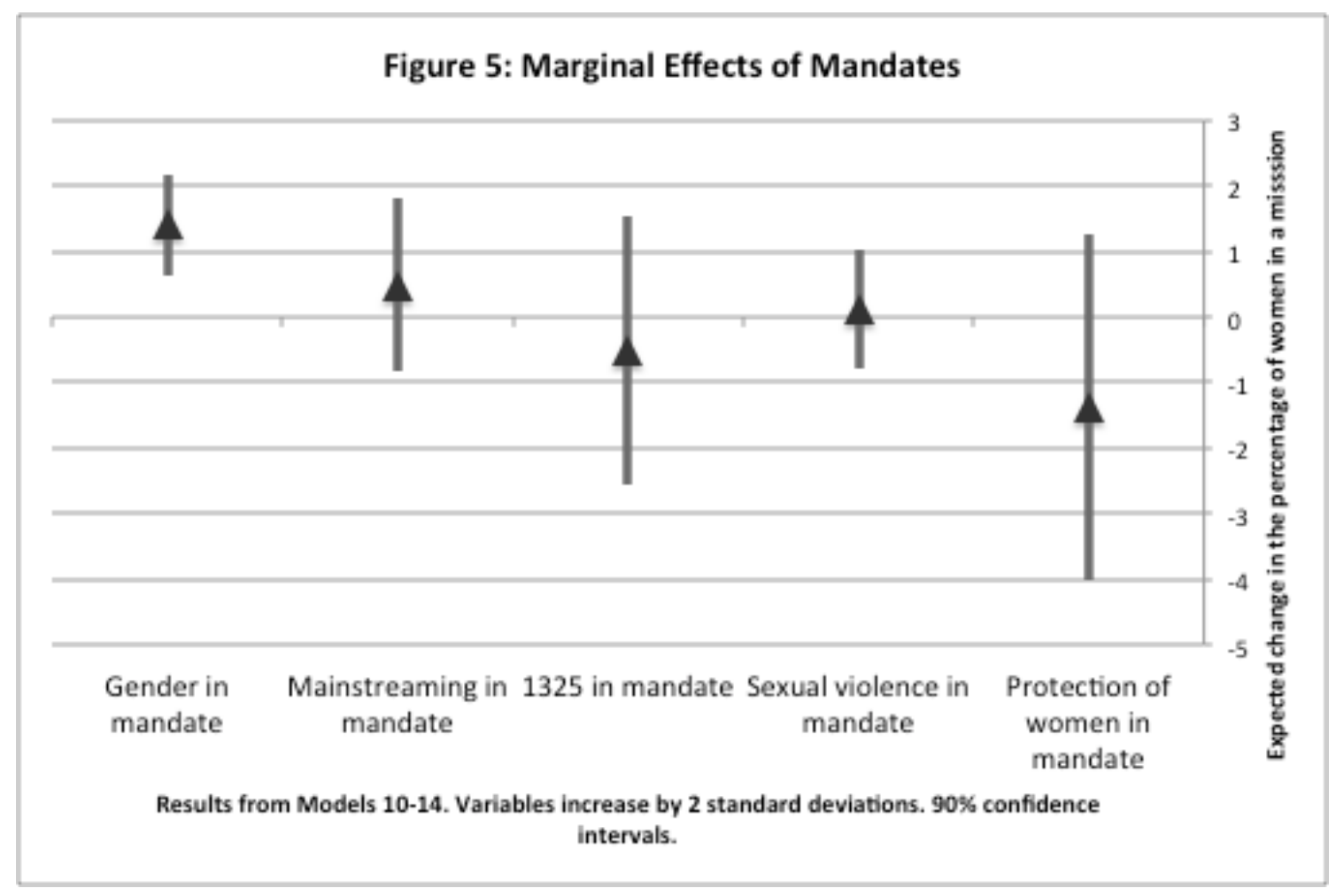


Table 1: Top 10 Contributors of Female PKO Contingent Troops, Nov. 2009Dec. 2011

\begin{tabular}{llccc}
\hline \hline Rank & Country & $\begin{array}{c}\text { Country's } \\
\text { contribution to } \\
\text { female troops }\end{array}$ & $\begin{array}{c}\text { Country's } \\
\text { contribution to } \\
\text { all troops }\end{array}$ & $\begin{array}{c}\text { Country's gender } \\
\text { balance }\end{array}$ \\
\hline 1 & South Africa & 0.135 & 0.024 & 0.142 \\
2 & Nigeria & 0.113 & 0.059 & 0.048 \\
3 & Ghana & 0.109 & 0.035 & 0.080 \\
4 & Ethiopia & 0.059 & 0.034 & 0.043 \\
5 & Uruguay & 0.058 & 0.029 & 0.050 \\
6 & Italy & 0.048 & 0.022 & 0.053 \\
7 & France & 0.043 & 0.017 & 0.061 \\
8 & Spain & 0.040 & 0.013 & 0.076 \\
9 & Nepal & 0.028 & 0.045 & 0.016 \\
10 & Kenya & 0.026 & 0.010 & 0.067 \\
\hline \hline
\end{tabular}

Note: Values are the averages across all months in the data 
Table 2: Top 10 PKOs by Gender Balance of Military Personnel, 2006-2011

\begin{tabular}{llcc} 
Rank & Mission & $\begin{array}{c}\text { Military Gender } \\
\text { Balance }\end{array}$ & $\begin{array}{c}\text { Avg Military } \\
\text { Personnel }\end{array}$ \\
\hline 1 & UNMIN (Nepal) & 0.068 & 1082 \\
2 & UNFICYP (Cyprus) & 0.062 & 9290 \\
3 & ONUB (Burundi) & 0.058 & 9862 \\
4 & UNISFA (South Sudan) & 0.055 & 13199 \\
5 & UNTSO (Middle East) & 0.054 & 1634 \\
6 & MINURSO (Western Sahara) & 0.040 & 2406 \\
7 & UNOMIG (Georgia) & 0.040 & 1106 \\
8 & UNMIT (Timor-Leste) & 0.034 & 351 \\
9 & UNIFIL (Lebanon) & 0.034 & 12973 \\
10 & UNMOGIP (India/Pakistan) & 0.026 & 464 \\
\hline \hline
\end{tabular}

Note: Values are the averages across all months in the data 
Table 3: Random Effects OLS, Mission Risk

\begin{tabular}{lc}
\hline \hline & 1 \\
\cline { 2 - 2 } PKO death rate & $-0.0657^{*}$ \\
Battle deaths, 10yrs (thousands) & $(0.0387)$ \\
& -0.0174 \\
GDP per capita (thousands) & $(0.0284)$ \\
& $0.155^{* *}$ \\
Traditional & $(0.0336)$ \\
& 0.0312 \\
Political & $(0.832)$ \\
& -0.179 \\
Constant & $(1.295)$ \\
& $3.015 * *$ \\
& $(0.696)$ \\
\hline R-squared & 0.30 \\
Observations & 115 \\
\hline \hline Standard errors in parentheses \\
$* p<0.05, * * p<0.01$ in a two-tailed test
\end{tabular}


Table 4: Random Effects OLS, Gender Needs

\begin{tabular}{|c|c|c|c|c|c|c|c|c|}
\hline & 2 & 3 & 4 & 5 & 6 & 7 & 8 & 9 \\
\hline One-sided violence fatalities & $\begin{array}{c}-0.00879 \\
(0.0107)\end{array}$ & & & & & & & \\
\hline PKO Allegations & & $\begin{array}{c}-0.0187 \\
(0.0177)\end{array}$ & & & & & & \\
\hline Female political representation & & & $\begin{array}{c}0.0140 \\
(0.0332)\end{array}$ & & & & & \\
\hline Primary school enrollment & & & & $\begin{array}{c}0.0178 \\
(0.0117)\end{array}$ & & & & \\
\hline Rape index & & & & & $\begin{array}{l}-0.103 \\
(0.403)\end{array}$ & & & \\
\hline Sex ratio (infanticide) index & & & & & & $\begin{array}{l}-0.0411 \\
(0.278)\end{array}$ & & \\
\hline Gender security index & & & & & & & $\begin{array}{l}-0.376 \\
(0.853)\end{array}$ & \\
\hline Gender law index & & & & & & & & $\begin{array}{l}-0.274 \\
(0.428)\end{array}$ \\
\hline GDP per capita (thousands) & $\begin{array}{l}0.160 * * \\
(0.0362)\end{array}$ & $\begin{array}{l}0.157 * * \\
(0.0343)\end{array}$ & $\begin{array}{l}0.161 * * \\
(0.0382)\end{array}$ & $\begin{array}{l}0.148^{* *} \\
(0.0318)\end{array}$ & $\begin{array}{l}0.153 * * \\
(0.0452)\end{array}$ & $\begin{array}{l}0.161 * * \\
(0.0384)\end{array}$ & $\begin{array}{l}0.141 * * \\
(0.0519)\end{array}$ & $\begin{array}{l}0.143 * * \\
(0.0415)\end{array}$ \\
\hline Traditional & $\begin{array}{c}0.570 \\
(0.656)\end{array}$ & $\begin{array}{c}0.431 \\
(0.693)\end{array}$ & $\begin{array}{c}0.657 \\
(0.649)\end{array}$ & $\begin{array}{c}0.457 \\
(0.607)\end{array}$ & $\begin{array}{c}0.606 \\
(0.654)\end{array}$ & $\begin{array}{c}0.626 \\
(0.735)\end{array}$ & $\begin{array}{c}0.607 \\
(0.655)\end{array}$ & $\begin{array}{c}0.598 \\
(0.636)\end{array}$ \\
\hline Political & $\begin{array}{l}-0.192 \\
(1.481)\end{array}$ & $\begin{array}{l}-0.363 \\
(1.518)\end{array}$ & $\begin{array}{l}-0.279 \\
(1.669)\end{array}$ & $\begin{array}{l}-0.475 \\
(1.401)\end{array}$ & $\begin{array}{l}-0.199 \\
(1.436)\end{array}$ & $\begin{array}{l}-0.174 \\
(1.479)\end{array}$ & $\begin{array}{l}-0.197 \\
(1.370)\end{array}$ & $\begin{array}{l}-0.156 \\
(1.486)\end{array}$ \\
\hline Constant & $\begin{array}{l}2.216 * * \\
(0.376)\end{array}$ & $\begin{array}{l}2.376 * * \\
(0.468)\end{array}$ & $\begin{array}{l}1.964 * * \\
(0.492)\end{array}$ & $\begin{array}{c}0.715 \\
(1.051)\end{array}$ & $\begin{array}{c}2.588 \\
(1.747)\end{array}$ & $\begin{array}{c}2.274 * * \\
(0.648)\end{array}$ & $\begin{array}{c}3.620 \\
(3.251)\end{array}$ & $\begin{array}{l}3.061 * \\
(1.497)\end{array}$ \\
\hline R-squared & 0.24 & 0.24 & 0.23 & 0.27 & 0.24 & 0.25 & 0.26 & 0.25 \\
\hline Observations & 115 & 115 & 115 & 115 & 115 & 115 & 115 & 115 \\
\hline
\end{tabular}

Standard errors in parentheses

$* p<0.05, * * p<0.01$ in a two-tailed test 
Table 5: Random Effects OLS, Mandates

\begin{tabular}{|c|c|c|c|c|c|}
\hline & 10 & 11 & 12 & 13 & 14 \\
\hline Gender in mandate & $\begin{array}{c}1.414^{* *} \\
(0.462)\end{array}$ & & & & \\
\hline Mainstreaming in mandate & & $\begin{array}{c}0.489 \\
(0.797)\end{array}$ & & & \\
\hline 1325 in mandate & & & $\begin{array}{l}-0.505 \\
(1.246)\end{array}$ & & \\
\hline Sexual violence in mandate & & & & $\begin{array}{c}0.116 \\
(0.543)\end{array}$ & \\
\hline Protection of women in mandate & & & & & $\begin{array}{c}-1.380 \\
(1.605)\end{array}$ \\
\hline GDP per capita (thousands) & $\begin{array}{c}0.157 * * \\
(0.0459)\end{array}$ & $\begin{array}{c}0.160 * * \\
(0.0403)\end{array}$ & $\begin{array}{l}0.157 * * \\
(0.0344)\end{array}$ & $\begin{array}{l}0.162 * * \\
(0.0375)\end{array}$ & $\begin{array}{c}0.147^{* *} \\
(0.0290)\end{array}$ \\
\hline Traditional & $\begin{array}{c}1.662 * \\
(0.731)\end{array}$ & $\begin{array}{c}0.963 \\
(0.864)\end{array}$ & $\begin{array}{c}0.191 \\
(1.210)\end{array}$ & $\begin{array}{c}0.687 \\
(0.742)\end{array}$ & $\begin{array}{c}-0.504 \\
(1.540)\end{array}$ \\
\hline Political & $\begin{array}{c}-0.176 \\
(1.385)\end{array}$ & $\begin{array}{l}-0.170 \\
(1.583)\end{array}$ & $\begin{array}{l}-0.346 \\
(1.212)\end{array}$ & $\begin{array}{l}-0.110 \\
(1.448)\end{array}$ & $\begin{array}{c}-0.312 \\
(1.146)\end{array}$ \\
\hline Constant & $\begin{array}{c}1.109 * * \\
(0.463)\end{array}$ & $\begin{array}{c}1.809 * * \\
(0.679)\end{array}$ & $\begin{array}{c}2.612 * \\
(1.138)\end{array}$ & $\begin{array}{c}2.087 * * \\
(0.525)\end{array}$ & $\begin{array}{c}3.360 * \\
(1.508)\end{array}$ \\
\hline R-squared & 0.27 & 0.22 & 0.26 & 0.24 & 0.28 \\
\hline Observations & 115 & 115 & 115 & 115 & 115 \\
\hline
\end{tabular}

Standard errors in parentheses

$* \mathrm{p}<0.05, * * \mathrm{p}<0.01$ in a two-tailed test 
Table 6: Random Effects OLS, Factors

\begin{tabular}{lc}
\hline \hline & 15 \\
\cline { 2 - 2 } Mission risk & $-2.153^{*}$ \\
Gender needs & $(0.976)$ \\
& -0.271 \\
Mandates & $(0.299)$ \\
& 0.326 \\
GDP per capita (thousands) & $(0.572)$ \\
& 0.0184 \\
Traditional & $(0.0783)$ \\
& 0.733 \\
Political & $(1.127)$ \\
& -0.133 \\
Constant & $(1.300)$ \\
& $2.556 *$ \\
R-squared & $(0.627)$ \\
Observations & 0.30 \\
\hline \hline
\end{tabular}

Standard errors in parentheses

$* p<0.05, * * p<0.01$ in a two-tailed test 